\title{
STUDI PERBANDINGAN PELAT BERUSUK DUA ARAH (WAFFLE SLAB) DAN PELAT KONVENSIONAL
}

\author{
Eka Susanti 1 , Nova Arie Youlanda 2 , Amrita Winaya 3 \\ Teknik Sipil ,FTSP ,ITATS Jl.Arief Rahman Hakim 100 Surabaya
}

\begin{abstract}
Plates with beams grid are also known as a Waffle Slab. Waffle Slab has several advantages, such as having great rigidity, thin plate thickness and the number of columns can be reduced so as to provide a broader space. The purpose of this study was to compare the Waffle Slab system with conventional plate system in terms of rigidity, thickness of the plate, the distance between the columns and the use of concrete material and reinforcement. Each plate system analyzed for maximum distance between the columns and the minimum thickness deflection license, SNI 03-2847-2002. Plate stiffness value is obtained by comparing the deflection occurs. The result is the conventional plate system is more rigid than the $47.42 \%$ waffle slab system, but a system of thin waffle slab over $40 \%$ and has a maximum spacing between columns Longer $55.57 \%$. This impact on the amount of the required fields. Waffle slab system requires a number of columns $55.55 \%$ less than the system reinforcement plate konvensional.The other result is waffle slab system use of concrete volume $27.64 \%$ more extravagant and wasteful use of steel reinforcement over $66.99 \%$ than conventional plate system.
\end{abstract}

Keywords: Waffle Slab, Conventional Plates, Stiffness, Deflection

\begin{abstract}
ABSTRAK
Pelat dengan balok grid dikenal juga dengan nama Waffle Slab. Pelat ini memiliki beberapa keuntungan, diantaranya adalah mempunyai kekakuan yang besar, tebal pelat yang tipis dan jumlah kolomkolomnya dapat dikurangi sehingga dapat memberi ruang yang lebih luas. Tujuan dari studi ini adalah membandingkan sistem Waffle Slab dengan sistem pelat konvensional ditinjau dari segi kekakuan, ketebalan pelat, jarak antar kolom dan penggunaan material beton dan tulangan. Masing-masing sistem pelat dianalisis terhadap jarak maksimal antar kolom dan tebal minimum pelat yang memenuhi lendutan ijin SNI 03-28472002. Nilai kekakuan pelat diperoleh dengan cara membandingkan lendutan yang terjadi. Dari hasil analisis tersebut ditarik kesimpulan bahwa sistem pelat konvensional lebih kaku 47,42\% dibanding sistem waffle slab, namun sistem waffle slab lebih tipis $40 \%$ dan memiliki jarak antar kolom maksimum lebih panjang $55,57 \%$. Hal ini memberikan dampak pada jumlah kolom yang diperlukan. Sistem waffle slab memerlukan jumlah kolom 55,55\% lebih sedikit dibanding dengan sistem pelat konvensional.Hasil analisis tulangan manunjukkan perbandingan penggunaan volume beton dan berat tulangan baja. Untuk sistem waffle slab, penggunaan volume beton lebih boros $27,64 \%$ dan penggunaan tulangan baja lebih boros $66,99 \%$ dibanding sistem pelat konvensional.
\end{abstract}

Kata Kunci : Waffle Slab, Pelat Konvensional, Kekakuan, Lendutan

\section{PENDAHULUAN}

Pelat adalah salah satu elemen struktur yang sifatnya lebih dominan terhadap lentur dengan bentuk yang melebar dan ketebalan yang relatif kecil. Sistem pelat terdiri dari beberapa macam yaitu sistem flat plate, sistem waffel slab, sistem flat slab, rib slab dan sistem pelat konvensional. Masing-masing sistem pelat memiliki kelebihan dan kekurangan tersendiri. Pemilihan berbagai sistem pelat ini disesuaikan dengan tujuan dari struktur yang diinginkan.

Penelitian mengenai perbandingan berbagai sistem pelat ini sudah dilakukan oleh beberapa peneliti. Diantaranya adalah penelitian mengenai perbandingan sistem pelat konvensional dan sistem flate slab ditinjau dari segi biaya struktur. Dari hasil analisis dapat disimpulkan bahwa secara keseluruhan, sistem flate slab memiliki biaya struktur yang paling murah [5]. Penelitian lainnya mengenai perbandingan sistem pelat konvensional, ribslab, flate slab dan flate slab dengan balok semu ditinjau dari segi biaya struktur. Dari hasil analisis dapat disimpulkan bahwa urutan 
sistem pelat yang memerlukan biaya konstruksi terendah yaitu pelat konvensional, flatslab, flatslab dengan balok semu, dan ribslab. Pelat konvensional merupakan sistem pelat yang membutuhkan biaya konstruksi yang paling rendah [6]. Dari kedua penelitian tersebut, belum dilakukan penelitian terhadap sistem waffle slab. Sistem pelat waffle Slab memiliki beberapa keuntungan, diantaranya adalah mempunyai kekakuan yang besar, jumlah kolom-kolomnya dapat dikurangi sehingga dapat memberi ruang yang lebih luas dan tebal pelat yang tipis [4].

Penelitian ini bertujuan membandingkan sistem struktur lantai waffle slab terhadap sistem konvensional ditinjau dari segi kekakuan, ketebalan pelat, jarak antar kolom dan penggunaan material beton serta tulangan.

\section{TINJAUAN PUSTAKA}

\section{Sistem Pelat}

Ada beberapa sistem pelat, diantaranya adalah sistem pelat konvensional, sistem waffle slab (pelat berusuk dua arah), sistem one joist slab (pelat berusuk satu arah), sistem flate plate dan sistem flate slab. Masing-masing pelat tersebut dibedakan oleh penggunaan sejumlah baloknya.

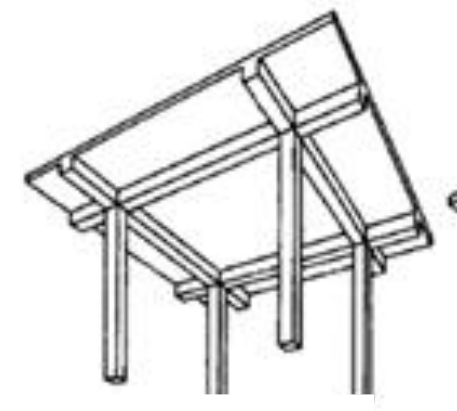

konvensional

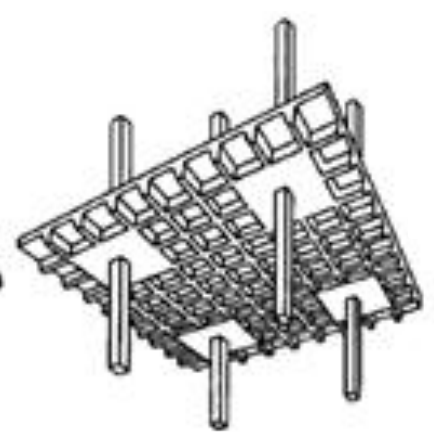

Waffle slab

Gambar1. Gambar sistem pelat konvensional dan sistem pelat waffle slab.

Pelat berusuk dua arah (waffle slab) yaitu kumpulan balok $\mathrm{T}$ yang saling menyilang dan menyatu pada bidang horizontal dimana gaya-gaya dominan yang bekerja adalah tegak lurus terhadap bidang tersebut dan titik hubung balok T ini bersifat kaku. Pada umumnya pelat berusuk dua arah (waffle slab) ini menggunakan bahan dari konstruksi beton bertulang dengan ketebalan pelat yang tipis dan pemakainan besi tulangan yang cukup hemat pada pelatnya dikarenakan pelat berusuk dua arah (waffle slab) ini memiliki kekakuan yang besar pada pelat sehingga lendutan pada pelat relatif kecil. Di sisi lain pelat berusuk dua arah (waffle slab) juga berpengaruh pada tata letak kolom. Semakin kecilnya lendutan pada balok maka jarak antar kolom pada portal bisa lebih jauh dari struktur yang biasa dan pada umumnya bisa mencapai bentang 7,5 - 12,5 meter [2].

Gambar (3), Gambar sistem flat plate. Flate plate atau pelat datar adalah sistem pelat yang meniadakan balok sebagai pendukung pelat. Penggunaan sistem ini membuat pelat menjadi lebih tebal dari pada tebal pelat dengan sistem konvensional. Sistem ini diminati karena waktu pekerjaan pelat relatif terkurangi dengan tidak adanya begisting balok.

Gambar (3), Gambar sistem flat slab. Konsep yang digunakan pada sistem ini hampir sama dengan sistem flate plate, hanya saja diperlukan penebalan pada kepala kolom.

\section{Lendutan Maksimum}

Pada suatu struktur beton harus disyaratkan mempunyai kekakuan yang cukup kuat, agar dapat menahan deformasi akibat lendutan tanpa menimbulkan kerusakan atau gangguan apa pun. Nilai lendutan yang terjadi tidak boleh melebihi nilai lendutan ijin yang disyaratkan dalam SNI 032847-2002 pasal 11.5.3. Yaitu sebesar: 
a. L/480 untuk Konstruksi atap atau lantai yang menahan atau disatukan dengan komponen nonstruktural yang mungkin akan rusak oleh lendutan besar.

b. L/240 untuk Konstruksi atap atau lantai yang menahan atau disatukan dengan komponen nonstruktural yang mungkin tidak akan rusak oleh lendutan besar.

\section{Tebal Pelat Minimum}

Berikut beberapa syarat ketentuan yang harus diperhatikan dalam menetukan tebal pelat untuk pelat konvensional dan waffle slab:

1) Menurut SNI 03-2847-2002 pasal 11.5.3, tebal minimum pelat pada sistem pelat konvensional bergantung pada $\alpha_{\mathrm{m}}$ :

(a) Jika $\alpha_{\mathrm{m}}<0,2 \mathrm{maka} \mathrm{h} \geq 120 \mathrm{~mm}$

(b) Jika $0,2 \leq \alpha_{\mathrm{m}} \leq 2$ maka:

$$
h=\frac{\operatorname{Ln}\left(0,8+\frac{f y}{1500}\right)}{36+5 \beta\left(\alpha_{m}-0,2\right)} \quad \text { dan } \geq 120 \mathrm{~m}
$$

(c) Jika $\alpha_{\mathrm{m}}>2$ maka:

$$
h=\frac{\operatorname{Ln}\left(0,8+\frac{f y}{1500}\right)}{36+9 \beta} \quad \text { dan } \geq 90 \mathrm{~m}
$$

dimana,

$\beta=$ Rasio bentang bersih pelat dalam arah memanjang dan arah memendek.

Ln = Panjang bersih pada arah memanjang dari konstruksi dua arah, yang diukur dari muka kemuka tumpuan pada pelat tanpa balok.

$\alpha \mathrm{m}=$ Nilai $\alpha$ rata-rata.

$\alpha \quad=$ rasio kekakuan lentur penampang balok terhadap kekakuan lentur pelat dengan rumus berikut:

$\alpha=\frac{E_{c} x I_{b}}{E_{c S} x I_{s}}$

Dimana:

$\mathrm{Ec}=$ Modulus elastisitas beton .

Ecs $=$ Modulus elastisitas pelat beton .

$\mathrm{Ib}=$ Momen inersia terhadap sumbu titik pusat penampang bruto balok.

Is = Momen inersia terhadap sumbu titik pusat penampang bruto pelat.

2) Menurut SNI 03-2847-2002 pasal 10.11.6.1 tebal pelat pada sistem waffle slab harus memenuhi syarat berikut:
(a) $h \geq 50 \mathrm{~mm}$
(b) $h \geq \frac{L n}{12}$

\section{Analisis Penulangan}

Disain penulangan dilakukan sesuai dengan SNI-2847-2002, dimana disain tulangan ditentukan oleh rasio tulangan. Untuk menjamin struktur dalam keadaan daktail, rasio tulangan harus berada diantara rasio tulangan minimum dan maksimum.

Rasio tulangan minimum, $\rho_{\text {min }}=\frac{1,4}{f y}$

Ratio tulangan maksimum $(\rho \max )=0,75 \rho \mathrm{b}$

$\rho b=\frac{0.85 \mathrm{fc} \prime}{\mathrm{fy}} \beta 1\left(\frac{600}{600+f y}\right)$

Dimana : $\quad f y=$ Mutu baja tulangan $(\mathrm{Mpa})$

$\mathrm{fc}^{\prime}=$ Mutu beton (Mpa) 
Jumlah luas tulangan yang diperlukan tergantung dari nilai rasio tulangan.

As $=\rho b d$

Dimana :

$$
\begin{aligned}
& \text { As }=\text { Luas Tulangan yang diperlukan } \\
& \rho=\text { Rasio tulangan } \\
& \text { b dan } \mathrm{d}=\text { dimensi elemen struktur beton }
\end{aligned}
$$

Dimensi elemen struktur dan jumlah tulangan yang digunakan memiliki kekuatan menahan beban yang disebut dengan kapasitas.
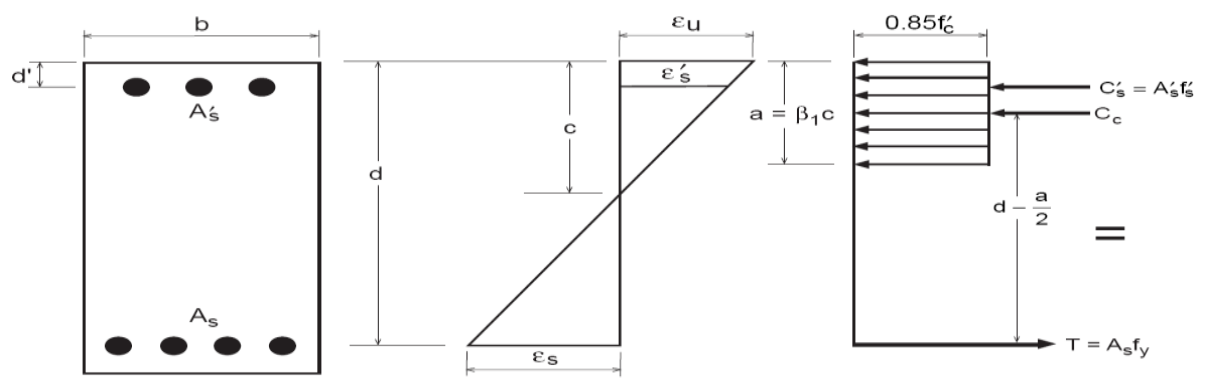

Gambar 2. penampang, diagram regangan dan diagram gaya

Kapasitas lentur beton bertulang adalah sebagai berikut:

$M_{n}=C_{c}\left(d-\frac{a}{2}\right)=0,85 f c^{\prime} a b\left(d-\frac{a}{2}\right)$

Atau

$M_{n}=T\left(d-\frac{a}{2}\right)=A_{s} f_{y}\left(d-\frac{a}{2}\right)$

Nilai kapasitas dari elemen struktur ini harus melebihi nilai momen lentur yang terjadi akibat adanya beban-beban. Ada beban mati, beban hidup dan beban gempa yang diperhitungkan dalam analisis pembebanan. Kombinasi ketiga beban tersebut dengan faktor bebannya, disebut beban ultimit [3]. Analisa struktur akan menganalisis gaya dalam yang terjadi pada elemen struktur tersebut akibat beban ultimit.Hasil analisis struktur untuk momen lentur adalah Momen Ultimit $(\mathrm{Mu})$. Nilai $\mathrm{Mu}$ ini yang harus memenuhi persamaan, $M_{u} \leq \varnothing M_{n}$ agar persyaratan keamanan struktur dapat dipenuhi.

\section{Geser}

(a) Untuk komponen-komponen struktur yang menahan geser dan lentur saja SNI 03-2847-

2002 pasal 13.3.1 memberikan kapasitas kemampuan beton untuk menahan geser adalah $\mathrm{v}_{\mathfrak{c}}$

$v_{c}=\left(\sqrt{\frac{f_{c \prime}}{6}}\right) \times b x d$

Dengan,

$\mathrm{v}_{\mathrm{c}}=$ Kuat geser nominal yang disumbangkan oleh beton

$\mathrm{f}_{\mathrm{c}}=$ Kuat tekan beton

$\mathrm{b}=$ Lebar balok

$\mathrm{d}=$ Jarak dari serat tekan terluar ke titik berat tulangan tarik longitudinal

(b) Apabila gaya geser yang bekerja $\mathrm{V}_{\mathrm{u}}$ lebih besar dari kapasitas geser beton $\varnothing \mathrm{v}_{\mathrm{c}}$ maka diperlakukan penulangan geser untuk memperkuatnya.

Dasar perencanaan tulangan geser adalah:

- $\varnothing \mathrm{v}_{\mathrm{n}} \geq \mathrm{v}_{\mathrm{u}} \quad$ (SNI 03-2847-2002 pasal 13.1.1)

- $\mathrm{v}_{\mathrm{n}}=\mathrm{v}_{\mathrm{c}}+\mathrm{v}_{\mathrm{s}} \quad($ SNI 03-2847-2002 pasal 13.1.1)

(c) Menurut SNI-03-2847-2002 pasal 13.1.3.1 bahwa $\mathrm{v}_{\mathrm{u}}$ boleh diambil pada jarak d (menjadi $\left.\mathrm{v}_{\mathrm{u}} \mathrm{d}\right)$ dari muka kolom sebagai berikut: 

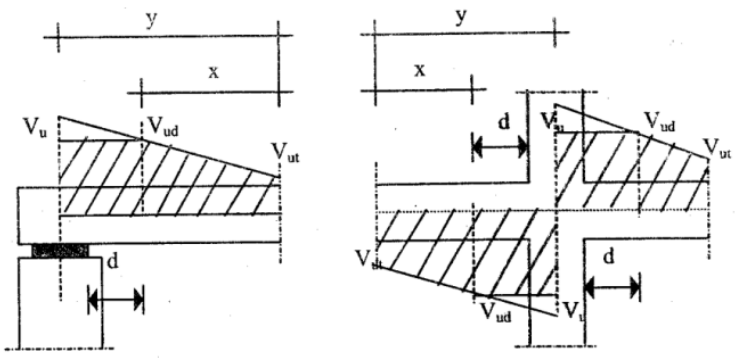

Gambar 3. Lokasi geser maksimal ( $\left.v_{u} d\right)$ untuk perencanaan

(d) Menurut SNI 03-2847-2002 pasal 13.5.6.1, gaya geser yang ditahan oleh tulangan sengkang $\left(\mathrm{V}_{\mathrm{s}}\right)$ dihitung berdasarkan persamaan sebagai berikut:

- $\mathrm{v}_{\mathrm{s}}=\left(\mathrm{v}_{\mathrm{u}}-\varnothing \mathrm{x} \mathrm{v}_{\mathrm{c}}\right) / \varnothing \quad($ SNI 03-2847-2002 pasal 13.5.6.1)

Dengan,

$$
\begin{aligned}
& \mathrm{v}_{\mathrm{n}}=\text { kuat geser nominal } \\
& \mathrm{v}_{\mathrm{s}}=\text { kuat geser nominal yang disumbangkan oleh tulangan geser } \\
& \varnothing \quad=\text { faktor reduksi }=0,75 \\
& \mathrm{v}_{\mathrm{u}}=\text { Gaya geser terfaktor pada penampang (boleh memakai Vud) }
\end{aligned}
$$

(e) Menurut SNI 03-2847-2002 pasal 13.5.6.6 bahwa:

$$
v_{s} \text { harus } \leq \frac{2}{3} \sqrt{f c^{\prime}} b d
$$

(f) Luas tulangan geser per meter panjang balok yang diperlukan $\left(A_{v, u}\right)$ dihitung dengan memilih nilai terbesar dari rumus berikut:

$$
\begin{array}{rlrl}
A_{v u} & =\frac{v_{s} x S}{f_{y} d} & & \text { (SNI 03-2847-2002 pasal 13.5.6.2) } \\
A_{v u}=\frac{b x S}{3 f_{y}} & (\text { SNI 03-2847-2002 pasal 13.5.5.3) } \\
A_{v u}=\frac{75 \sqrt{f c^{\prime}}(b x S)}{1200 f_{y}} & (\text { SNI 03-2847-2002 pasal 13.5.5.3) }
\end{array}
$$

Spasi begel (s) dihitung dengan rumus berikut:

$s=\frac{n x 1 / 4 \pi(d p)^{2} s}{A_{v u}}$

Dimana:

$\mathrm{n}$ = Jumlah kaki begel ( 2,3 , atau 4 kaki)

$\mathrm{dp}=$ diameter begel dari tulangan polos

SNI 03-2847-2002 pasal 13.5.4.1 menyatakan $\mathrm{s} \leq \mathrm{d} / 2$ dan $\mathrm{s} \leq 600 \mathrm{~mm}$ bila:

$$
v_{s}<1 / 3 \sqrt{f c^{\prime}}(b d)
$$

SNI 03-2847-2002 pasal 13.5.4.3 menyatakan $\mathrm{s} \leq \mathrm{d} / 4$ dan $\mathrm{s} \leq 300 \mathrm{~mm}$ bila:

$$
v_{s}>1 / 3 \sqrt{f c^{\prime}}(b d)
$$

\section{METODE}

Metode penelitian ini bersifat studi permodelan struktur menggunakan softwear SAP 2000 v.14 dengan langkah seperti terlihat pada diagram alir berikut: 


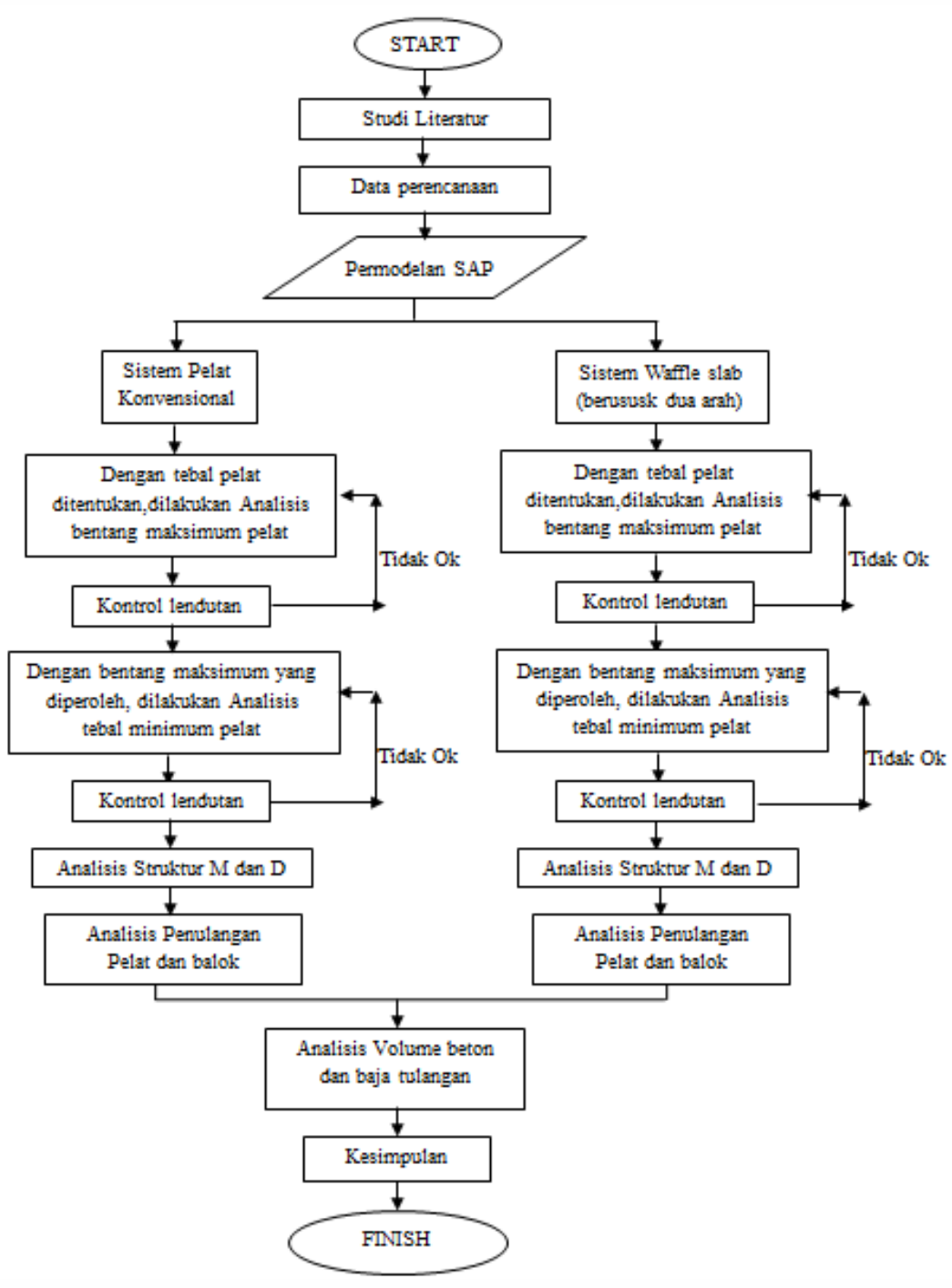

Gambar 4. Diagram alir penelitian

\section{HASIL DAN PEMBAHASAN}

\section{Permodelan Struktur 3D Pada Program SAP 2000 v.14}

Berikut permodelan 3D pelat dengan menggunakan sistem waffle slab dan pelat konvensional pada program SAP 2000 v.14:

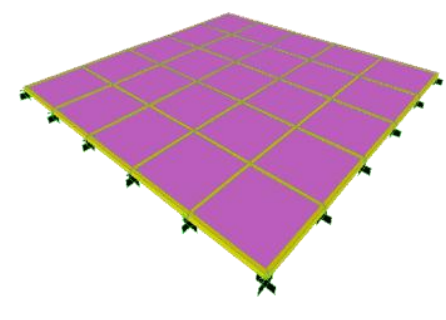

waffle slab

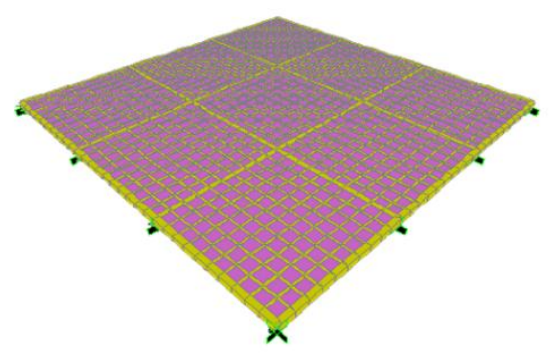

konvensional

Gambar 5. Permodelan SAP 2000 untuk sistem pelat waffle slab dan konvensional 
Pada permodelan sistem waffle slab terlihat, bahwa diantara balok-balok utama, ada balok-balok kecil (balok rusuk) yang membagi pelat dalam panel yang lebih kecil-kecil.

\section{Analisis Bentang Maksimum Pelat}

Dengan menetapkan tebal pelat 120mm, ukuran balok 40/60 dan ukuran balok rusuk 20/40, dilakukan analisis bentang maksimum pelat terhadap sistem waffle slab dan sistem pelat konvensional. Hasil analisis ditabelkan sebagai berikut:

Tabel 1. Analisis bentang maksimum pelat

\begin{tabular}{|c|c|c|c|c|c|c|c|}
\hline \multirow{3}{*}{ No } & \multirow{3}{*}{$\begin{array}{l}\text { Jarak antar } \\
\text { kolom }(\mathrm{m})\end{array}$} & \multicolumn{3}{|c|}{ Sistem Waffle Slab } & \multicolumn{3}{|c|}{ Sistem Pelat Konvensional } \\
\hline & & \multirow{2}{*}{$\begin{array}{l}\text { Lendutan max } \\
(\mathrm{mm})\end{array}$} & \multicolumn{2}{|c|}{ Lendutan ijin } & \multirow{2}{*}{$\begin{array}{l}\text { Lendutan } \\
\text { max }\end{array}$} & \multicolumn{2}{|c|}{ Lendutan ijin } \\
\hline & & & $\mathrm{L} / 480$ & $\mathrm{~L} / 240$ & & $\mathrm{~L} / 480$ & $\mathrm{~L} / 240$ \\
\hline 1 & 15 & 123,38 & 31,25 & 62,5 & 332,16 & 31,25 & 62,5 \\
\hline 2 & 10 & 21,82 & 20,83 & 41,17 & 61,42 & 20,83 & 41,67 \\
\hline 3 & 6 & 2,44 & 12,5 & 25,00 & 7,49 & 12,5 & 25 \\
\hline 4 & 5 & 1,05 & 10,42 & 20,83 & 3,56 & 10,42 & 20,83 \\
\hline
\end{tabular}

Berdasarkan dari tabel .1 menunjukkan :

a. Sistem Waffle Slab

Lendutan yang terjadi pada jarak antar perletakan 10 meter sebesar 21,82 mm lebih kecil dari lendutan ijin L/240 sebesar 41,17 mm . Namun nilai ini sedikit lebih besar dari lendutan ijin L/480 sebesar 20,83. Pada tahap analisis bentang maksimum ini untuk sistem waffle slab dipilih bentang $\max 10 \mathrm{~m}$. Tahap selanjutnya analisis tebal minimum pelat, tebal pelat akan dikurangi, dengan harapan diperoleh tebal pelat minimum dengan bentang max $10 \mathrm{~m}$ dapat memenuhi persyaratan kedua lendutan ijin tersebut.

b. Sistem Pelat Konvensional

Lendutan yang terjadi pada jarak antar perletakan 6 meter yaitu sebesar 3,56 mm sudah memenuhi persyaratan lendutan ijin dengan persamaan L/240 maupun L/480. Sehingga dapat digunakan bentang maksimum 6 meter .

c. Dengan jarak antar kolom yang sama dan tebal pelat yang sama, lendutan pelat dengan sistem pelat konvensional lebih besar dibanding sistem waffle slab. Bila dirata-rata, maka terdapat perbedaan nilai lendutan sebesar $200 \%$.

\section{Analisis Tebal Minimum Pelat}

Berdasarkan bentang maksimum pelat, dilakukan analisis tebal minimum pelat. Untuk sistem waffle slab digunakan bentang $10 \mathrm{~m}$ dan jarak antar balok rusuk $1 \mathrm{~m}$. Sedangkan untuk sistem pelat konvensional digunakan bentang maksimum $6 \mathrm{~m}$. Hasil analisis tebal minimum pelat ditabelkan sebagai berikut:

Tabel 2. Analisis tebal minimum pelat

\begin{tabular}{|c|c|c|c|c|c|c|c|}
\hline \multirow{3}{*}{ No } & \multirow{3}{*}{$\begin{array}{c}\text { Tebal } \\
\text { minimum } \\
\text { pelat }(\mathrm{mm})\end{array}$} & \multicolumn{3}{|c|}{ Sistem Waffle Slab } & \multicolumn{3}{|c|}{ Sistem Pelat Konvensional } \\
\hline & & \multirow{2}{*}{$\begin{array}{l}\text { Lendutan max } \\
(\mathrm{mm})\end{array}$} & \multicolumn{2}{|c|}{ Lendutan ijin } & \multirow{2}{*}{$\begin{array}{l}\text { Lendutan } \\
\max \end{array}$} & \multicolumn{2}{|c|}{ Lendutan ijin } \\
\hline & & & $\mathrm{L} / 480$ & $\mathrm{~L} / 240$ & & $\mathrm{~L} / 480$ & $\mathrm{~L} / 240$ \\
\hline 1 & 120 & 21,82 & & & 7,49 & & \\
\hline 2 & 110 & 21,51 & & & 8,71 & & \\
\hline 3 & 100 & 21,17 & & & 10,3 & & \\
\hline 4 & 90 & 20,81 & 20,83 & 41,67 & 12,97 & 12,5 & 25 \\
\hline 5 & 80 & 20,43 & & & - & & \\
\hline 6 & 70 & 20,04 & & & - & & \\
\hline 7 & 60 & 19,64 & & & - & & \\
\hline
\end{tabular}


Berdasarkan hasil dari tabel. 2 :

a. Sistem Waffle Slab

Lendutan yang terjadi pada tebal pelat $60 \mathrm{~mm}$ yaitu sebesar 19,64 mm sudah memenuhi persyaratan lendutan ijin dengan persamaan L/240 dan L/480. Pada tahap ini untuk sistem waffle slab dipilih tebal pelat $60 \mathrm{~mm}$

b. Sistem Pelat Konvensional

Lendutan yang terjadi pada tebal pelat minimum $100 \mathrm{~mm}$ yaitu sebesar $12,97 \mathrm{~mm}$ sudah memenuhi persyaratan lendutan ijin dengan persamaan L/240 dan L/480.

\section{Analisis Penulangan}

Berdasarkan bentang maksimum pelat dan tebal minimum pelat dilakukan analisis pembebanan, analisis struktur dan analisis penulangan.

Tabel 3. Data analisis pelat

\begin{tabular}{lccc}
\hline Jenis Pelat & $\begin{array}{c}\text { Jarak antar } \\
\text { balok }\end{array}$ & $\begin{array}{c}\text { Jarak } \\
\text { balok } \\
\text { rusuk }\end{array}$ & $\begin{array}{c}\text { Tebal } \\
\text { pelat }\end{array}$ \\
\hline Waffle Slab & $10 \mathrm{~m}$ & $1 \mathrm{~m}$ & $60 \mathrm{~mm}$ \\
\hline Konvensional & $6 \mathrm{~m}$ & - & $100 \mathrm{~mm}$ \\
\hline
\end{tabular}

Berdasarkan data tabel 3, dilakukan analisis dengan hasil analisis sebagai berikut:

\section{a. Analisis Struktur}

Analisis struktur dilakukan dengan bantuan software SAP 200 v.14. Hasil analisis struktur pelat berupa momen dapat dilihat pada tabel 4 , hasil analisa struktur balok berupa momen dapat dilihat pada tabel 5 dan gaya lintang dapat dilihat pada tabel 6 .

Tabel 4. Hasil Analisis Srtuktur Pelat (Momen)

\begin{tabular}{ccc}
\hline \multirow{2}{*}{ Jenis Pelat } & \multicolumn{2}{c}{ M11 } \\
\cline { 2 - 3 } & $\begin{array}{c}\mathrm{M}_{\text {tump }} \\
(\mathrm{N} . \mathrm{mm})\end{array}$ & $\begin{array}{c}\mathrm{M}_{\text {lap }} \\
(\mathrm{N} . \mathrm{mm})\end{array}$ \\
\hline Waffle Slab & 612,2 & 195,1 \\
\hline Konvensional & 5018,48 & 2286,32 \\
\hline
\end{tabular}

Tabel 5. Hasil Analisis Struktur Balok (Momen)

\begin{tabular}{ccccccc}
\hline \multirow{2}{*}{ Jenis Pelat } & \multicolumn{2}{c}{ Balok Tengah } & \multicolumn{2}{c}{ Balok Tepi } & \multicolumn{2}{c}{ Balok Rusuk } \\
\cline { 2 - 6 } & $\begin{array}{c}\mathrm{M}_{\text {tump }} \\
(\mathrm{N} . m m)\end{array}$ & $\begin{array}{c}\mathrm{M}_{\text {lap }} \\
(\mathrm{N} . \mathrm{mm})\end{array}$ & $\begin{array}{c}\mathrm{M}_{\text {tump }} \\
(\mathrm{N} . \mathrm{mm})\end{array}$ & $\begin{array}{c}\mathrm{M}_{\text {lap }} \\
(\mathrm{N} . \mathrm{mm})\end{array}$ & $\begin{array}{c}\mathrm{M}_{\text {tump }} \\
(\mathrm{N} . \mathrm{mm})\end{array}$ & $\begin{array}{c}\mathrm{M}_{\text {lap }} \\
(\mathrm{N} . \mathrm{mm})\end{array}$ \\
\hline Waffle Slab & 648,78 & 288,74 & 304,85 & 154,62 & 80,29 & 41,93 \\
\hline & $\mathrm{M}_{\text {tump }}$ & $\mathrm{M}_{\text {lap }}$ & & & & \\
& Balok & Balok & & & & \\
& $(\mathrm{N} . \mathrm{mm})$ & $(\mathrm{N} . \mathrm{mm})$ & & & & \\
\hline Konvensional & 119,9 & 69,87 & & & & \\
\hline
\end{tabular}


Tabel 6. Hasil Analisis Struktur Balok (Gaya Lintang)

\begin{tabular}{|c|c|c|c|c|c|c|}
\hline \multirow[b]{2}{*}{ Jenis Pelat } & \multicolumn{2}{|c|}{ Balok Tengah } & \multicolumn{2}{|c|}{ Balok Tepi } & \multicolumn{2}{|c|}{ Balok Rusuk } \\
\hline & $\begin{array}{l}\mathrm{D}_{\text {tump }} \\
(\mathrm{KN})\end{array}$ & $\begin{array}{c}D_{\text {lap }} \\
(\mathrm{KN})\end{array}$ & $\begin{array}{l}D_{\text {tump }} \\
(\mathrm{KN})\end{array}$ & $\begin{array}{c}\mathrm{D}_{\text {lap }} \\
(\mathrm{KN})\end{array}$ & $\begin{array}{l}\mathrm{D}_{\text {tump }} \\
(\mathrm{KN})\end{array}$ & $\begin{array}{c}\mathrm{D}_{\text {lap }} \\
(\mathrm{KN})\end{array}$ \\
\hline Waffle Slab & 398,54 & 31,45 & 166,59 & 16,4 & 45,25 & 3,19 \\
\hline & $\begin{array}{l}D_{\text {tump }} \\
(\mathrm{KN})\end{array}$ & $\begin{array}{c}D_{\text {lap }} \\
(\mathrm{KN})\end{array}$ & & & & \\
\hline Konvensional & 99,48 & 4,22 & & & & \\
\hline
\end{tabular}

b. Rekapitulasi Penulangan Pelat

Berdasarkan hasil analisis struktur pelat berupa momen, nilainya digunakan untuk analisis penulangan pelat. Hasil analisis penulangan pelat dengan sistem waffle slab dapat dilihat pada tabel 7. Dan hasil analisis penulangan pelat dengan sistem pelat konvensional dapat dilihat pada tabel 8 dibawah ini.

Tabel 7. Hasil analisis penulangan pelat dengan sistem waffle slab

\begin{tabular}{cccc}
\multicolumn{2}{c}{ Arah X } & \multicolumn{2}{c}{ Arah Y } \\
\hline $\begin{array}{c}\text { As } \\
\left(\mathrm{mm}^{2}\right)\end{array}$ & $\begin{array}{c}\text { tul } \\
\text { pasang }\end{array}$ & $\begin{array}{c}\text { As } \\
\left(\mathrm{mm}^{2}\right)\end{array}$ & tul pasang \\
\hline 210 & $\varnothing 8-200$ & 163,33 & $\varnothing 8-300$ \\
\hline
\end{tabular}

Tabel 8. Hasil analisis penulangan pelat dengan sistem pelat konvensional

\begin{tabular}{|c|c|c|c|c|c|c|c|c|c|}
\hline \multicolumn{4}{|c|}{$\operatorname{Arah} X$} & \multicolumn{4}{|c|}{ Arah Y } & \multirow{2}{*}{\multicolumn{2}{|c|}{ susut }} \\
\hline \multicolumn{2}{|c|}{ Lapangan } & \multicolumn{2}{|c|}{ Tumpuan } & \multicolumn{2}{|c|}{ Lapangan } & \multicolumn{2}{|c|}{ Tumpuan } & & \\
\hline $\begin{array}{c}\text { As } \\
\left(\mathrm{mm}^{2}\right)\end{array}$ & tul pasang & $\begin{array}{c}\text { As } \\
\left(\mathrm{mm}^{2}\right)\end{array}$ & tul pasang & $\begin{array}{c}\text { As } \\
\left(\mathrm{mm}^{2}\right)\end{array}$ & $\begin{array}{c}\text { tul } \\
\text { pasang }\end{array}$ & $\begin{array}{c}\text { As } \\
\left(\mathrm{mm}^{2}\right)\end{array}$ & $\begin{array}{c}\text { tul } \\
\text { pasang }\end{array}$ & $\begin{array}{c}\text { As } \\
\left(\mathrm{mm}^{2}\right)\end{array}$ & $\begin{array}{c}\text { tul } \\
\text { pasang }\end{array}$ \\
\hline 503 & $\varnothing 8-100$ & 503 & $\varnothing 8-100$ & 503 & $\varnothing 8-100$ & 503 & $\varnothing 8-100$ & 180 & $\varnothing 6-150$ \\
\hline
\end{tabular}

\section{c. Rekapitulasi Penulangan Balok}

Berdasarkan hasil analisis struktur balok yaitu momen dan gaya lintang dilakukan analisis tulangan balok. Momen digunakan untuk analisis tulangan longitudinal balok. Hasil analisis tulangan longitudinal balok dengan sistem waffle slab dan konvensional dapat dilihat pada tabel 9

Dan gaya lintang, digunakan untuk analisis tulangan geser balok. Hasil analisis tulangan geser balok dengan sistem waffle slab dan konvensional dapat dilihat pada tabel 10 .

Tabel 9. Hasil analisis tulangan longitudinal balok

\begin{tabular}{cccccccc}
\hline \multirow{3}{*}{ Jenis Pelat } & & \multicolumn{2}{c}{ Balok Tengah } & \multicolumn{2}{c}{ Balok Tepi } & \multicolumn{2}{c}{ Balok Rusuk } \\
& \multirow{2}{*}{ Tulangan } & \multicolumn{2}{c}{$(40 / 60)$} & \multicolumn{2}{c}{$(40 / 60)$} & \multicolumn{2}{c}{ (20/40) } \\
\cline { 2 - 7 } & & Tul. & Tul. & Tul. & Tul. & Tul. & Tul. \\
& Tump & Lap & Tump & Lap & Tump & Lap \\
\hline \multirow{2}{*}{ Waffle Slab } & Tarik & 12D22 & 5D22 & 10D16 & 5D16 & 6D14 & 3D14 \\
& Tekan & 4D22 & 2D22 & 2D16 & 2D16 & 2D14 & 2D14 \\
\hline \multirow{3}{*}{ Konvensional } & Tul. & Tul. & & & & \\
& & Tump & Lap & & & & \\
& Tarik & 2D12 & 2D12 & & & & \\
& Tekan & 2D12 & 2D12 & & &
\end{tabular}


Tabel 10. Hasil analisis tulangan geser balok

\begin{tabular}{|c|c|c|c|c|c|c|}
\hline \multirow{2}{*}{ Jenis Pelat } & \multicolumn{2}{|c|}{$\begin{array}{c}\text { Balok Tengah } \\
(40 / 60)\end{array}$} & \multicolumn{2}{|c|}{$\begin{array}{l}\text { Balok Tepi } \\
(40 / 60)\end{array}$} & \multicolumn{2}{|c|}{$\begin{array}{l}\text { Balok Rusuk } \\
\text { (20/40) }\end{array}$} \\
\hline & $\begin{array}{l}\text { Tul. } \\
\text { Tump }\end{array}$ & $\begin{array}{l}\text { Tul. } \\
\text { Lap }\end{array}$ & $\begin{array}{l}\text { Tul. } \\
\text { Tump }\end{array}$ & $\begin{array}{l}\text { Tul. } \\
\text { Lap }\end{array}$ & $\begin{array}{l}\text { Tul. } \\
\text { Tump }\end{array}$ & $\begin{array}{l}\text { Tul. } \\
\text { Lap }\end{array}$ \\
\hline Waffle Slab & $\begin{array}{c}3 \Phi 8- \\
100\end{array}$ & $\begin{array}{l}\Phi 8- \\
250\end{array}$ & $\begin{array}{l}8- \\
250\end{array}$ & $\begin{array}{l}6- \\
250\end{array}$ & $\begin{array}{l}\Phi 8- \\
150\end{array}$ & $\begin{array}{l}\Phi 6- \\
150 \\
\end{array}$ \\
\hline & $\begin{array}{l}\text { Tul. } \\
\text { Tump }\end{array}$ & $\begin{array}{l}\text { Tul. } \\
\text { Lap }\end{array}$ & & & & \\
\hline Konvensional & $\Phi 6-250$ & $\begin{array}{l}\Phi 8- \\
250\end{array}$ & & & & \\
\hline
\end{tabular}

\section{d. Rekapitulasi Volume beton dan baja tulangan}

Berdasarkan hasil analisis penulangan pelat dan balok, maka diperoleh kebutuhan volume beton dan berat baja tulangan untuk masing-masing sistem pelat yang digunakan. Hasil analisis volume beton dan berat baja tulangan dapat dilihat pada tabel 8 dibawah ini.

Tabel 8. Hasil analisis Volume beton

\begin{tabular}{|c|c|c|c|c|c|}
\hline \multicolumn{3}{|c|}{ Sistem waffle Slab } & \multicolumn{3}{|c|}{ Sistem Pelat Konvensional } \\
\hline Keterangan & $\begin{array}{l}\text { Volume } \\
\text { beton } \\
\left(\mathrm{m}^{3}\right)\end{array}$ & $\begin{array}{l}\text { Berat baja } \\
\text { tulangan } \\
(\mathrm{kg})\end{array}$ & Keterangan & $\begin{array}{l}\text { Volume beton } \\
\qquad\left(\mathrm{m}^{3}\right)\end{array}$ & $\begin{array}{c}\text { Berat baja } \\
\text { tulangan } \\
(\mathrm{kg})\end{array}$ \\
\hline $\begin{array}{c}\text { Pelat }(\mathrm{t}=60 \mathrm{~mm}) \\
\text { D8-300 } \\
\text { D8-200 }\end{array}$ & 55,45 & $\begin{array}{l}1780,41 \\
1190,87\end{array}$ & $\begin{array}{c}\text { Pelat }(\mathrm{t}=120 \\
\mathrm{mm}) \\
\mathrm{D} 8-200 \\
\text { D6-150(tul } \\
\text { susut) }\end{array}$ & 92,42 & $\begin{array}{c}9538,7 \\
1563\end{array}$ \\
\hline $\begin{array}{c}\text { Balok } \\
\text { Tengah(40/60) } \\
\text { 16D22 } \\
\text { 7D22 } \\
\text { 3D8-100 } \\
\text { D8-250 }\end{array}$ & 25,23 & $\begin{array}{c}3223,52 \\
1203,09 \\
815,43 \\
84,09\end{array}$ & $\begin{array}{c}\text { Balok (40/60) } \\
\text { 4D22 } \\
\text { D8-250 } \\
\text { D6-250 }\end{array}$ & 70,2 & $\begin{array}{l}4518,28 \\
483,, 32 \\
123,37\end{array}$ \\
\hline $\begin{array}{c}\text { Balok Tepi (40/60) } \\
\text { 12D16 } \\
\text { 7D16 } \\
\text { D8-250 } \\
\text { D6-250 } \\
\end{array}$ & 25,23 & $\begin{array}{c}1260,57 \\
636,35 \\
215,83 \\
62,21\end{array}$ & & & \\
\hline $\begin{array}{c}\text { Balok rusuk } \\
(20 / 40) \\
8 D 14 \\
5 D 14 \\
\text { D8-150 } \\
\text { D6-150 }\end{array}$ & 100,98 & $\begin{array}{c}8644,37 \\
4698,03 \\
2370,62 \\
92,76\end{array}$ & & & \\
\hline TOTAL & 207,58 & 27098,14 & & 162,62 & 15743,35 \\
\hline
\end{tabular}




\section{KESIMPULAN}

Dari analisis yang telah dilakukan dapat disimpulkan bahwa :

1. Dengan jarak antar kolom yang sama dan tebal pelat yang sama, lendutan pelat dengan sistem pelat konvensional lebih besar dibanding sistem waffle slab. Bila dirata-rata, maka terdapat perbedaan nilai lendutan sebesar $200 \%$.

2. Jarak antar perletakan maksimum pada pelat dengan sistem waffle slab adalah 10 meter dan pelat dengan sistem konvensional adalah 6 meter sehingga jarak antar perletakan pada sistem waffle slab lebih panjang $66,67 \%$ dibanding dengan sistem pelat konvensional.

3. Hal ini berdampak pada penggunaan jumlah kolom, pada sistem waffle slab memiliki jumlah kolom 16 buah dan pada sistem pelat konvensional memiliki jumlah kolom 36 buah sehingga sistem waffle slab dapat menghemat penggunaan kolom sebesar 55,57\% dibanding dengan sistem pelat konvensional.

4. Tebal pelat pada sistem waffle slab adalah $60 \mathrm{~mm}$ dan tebal pelat dengan sistem konvensional adalah $120 \mathrm{~mm}$. Sehingga sistem waffle slab memiliki tebal pelat lebih tipis $40 \%$ dari sistem pelat konvensional.

5. Volume beton pada sistem waffle slab lebih boros $27,64 \%$ dari sistem pelat konvensional

6. Berat tulangan baja pada sistem waffle slab lebih boros $66,99 \%$ dari sistem pelat konvensional.

\section{DAFTAR PUSTAKA}

[1] Asroni, H.Ali.2010. Balok dan Pelat Beton Bertulang. Yogyakarta: Graha Ilmu.

[2] Nasution, Amrisyah.2009. Analisis dan Desain Struktur Beton Bertulang. Bandung: ITB.

[3] PPIUG, 1983 Peraturan Pembebanan Indonesia Untuk Gedung. Direktorat Penyelidikan Masalah Bangunan.

[4] Puspantoro, M.Sc, Ir.Ign.Benny.1993. Teori \& Analisis Balok Grid. Yogyakarta: Andi Offset.

[5] Dudun Anugerah W, 2011, STUDI PENGARUH SISTEM STRUKTUR LANTAI BETON BERTULANG TERHADAP BIAYA KONSTRUKSI, ITS

[6] Denny Ervianto, 2012, STUDI PERBANDINGAN PELAT KONVENTIONAL, RIBSLAB DAN FLATSLAB BERDASARKAN BIAYA KONSTRUKSI, ITS 
- Halaman ini sengaja dikosongkan - 